\title{
Próba oceny rozwoju polskiej wsi pięć lat po przystappieniu do Unii Europejskiej
}

\section{Wprowadzenie}

Wstąpienie Polski do Unii Europejskiej (UE) spowodowało wiele pozytywnych zmian w rolnictwie i na wsi. Za sukces należy uznać włączenie się polskiej branży rolno-spożywczej w jednolity rynek UE. Przez 5 lat Polska dostosowała swoje prawodawstwo i zbudowała system wdrażania instrumentów Wspólnej Polityki Rolnej (WPR). Pięcioletnie doświadczenie we wdrażaniu WPR daje Polsce prawo do dyskusji nad nowymi rozwiązaniami po 2013 roku. Warto jednak byłoby zastanowić się nad uproszczeniem polityki rolnej.

Polska proponuje taki model płatności by dopłaty bezpośrednie były związane wyłącznie z powierzchnią gospodarstwa i uwzględniały konieczność produkcji rolniczej w zgodzie ze środowiskiem naturalnym. Z kolei płatności ONW (obszary o niekorzystnych warunkach) z tytułu gospodarowania w niekorzystnych warunkach powinny być przeniesione $\mathrm{z}$ tzw. II filara (funduszy przeznaczonych na rozwój terenów wiejskich) do I filara (środków przeznaczonych na finansowanie rolnictwa), gdyż dopłaty bezpośrednie powinny finansować część kosztów produkcji rolnej. Realizacja działania powinna zapobiegać wyludnianiu się obszarów wiejskich, zakwalifikowanych jako górskie i inne o niekorzystnych warunkach gospodarowania i zatracaniu ich rolniczego charakteru oraz wiążącymi się z tym konsekwencjami społecznymi, gospodarczymi i środowiskowymi. Płatności ONW powinny stanowić rekompensatę za poniesione koszty i dochód utracony w wyniku gospodarowania na tych obszarach (Ryś-Jurek, 2008).

W UE nie powinno być kilku polityk rolnych, oddzielnych dla każdego z państw, ale jedna wspólna polityka, która dawałaby rolnikom równe szanse na unijnym rynku. Niestety nowe państwa członkowskie mają nierówne szanse na jednolitym rynku, gdyż mają różny poziom wsparcia. Warto poszukiwać takich rozwiązań, by po 2013 roku warunki konkurencji były wyrównane.

W 2004 roku większość rolników była przeciwna wstąpieniu Polski do UE, bowiem negatywnie oceniali 10-letni okres stowarzyszeniowy (Chmielewska, 
2006; Ryś-Jurek, 2008). Rynek naszego kraju był wówczas otwarty dla żywności unijnej, lecz Polska miała ograniczenia w eksporcie swoich produktów. Obecnie raczej wszyscy są zgodni, że akcesja Polski do UE była korzystna dla rolnictwa i gospodarki żywnościowej. Unijne pieniądze pozwoliły na modernizację polskiej wsi i unowocześniły przemysł przetwórczy. Wśród korzyści najczęściej wymieniane są m.in.: otwarcie unijnego rynku, wzrost dochodów rolników, stabilność polityki rolnej, a także podniesienie standardów produkcji żywności (Bański, 2006).

Największa korzyść dla Polski wynika z otwarcia unijnych rynków dla eksportu żywności. Obecnie producenci mogą wywozić produkty bez żadnych barier celnych. Dostęp do wspólnotowego rynku zaowocował prawie 3-krotnym wzrostem eksportu. Unia powinna w większym stopniu wspierać eksport nadwyżek żywności do innych krajów nie należących do UE. Chodzi o dopłacanie do tych produktów, aby mogły łatwo znajdować nabywców. Obecnie poprzez Agencję Rynku Rolnego (ARR) dopłatę mogą otrzymać m.in. eksporterzy mleka i masła. Według ekspertów polskie rolnictwo bardzo zyskuje na transferach środków przekazywanych $\mathrm{w}$ ramach WPR. Są one przekazywane przez UE w formie dopłat bezpośrednich oraz w ramach unijnych programów pomocowych, m.in.: Programu Rozwoju Obszarów Wiejskich (PROW). W latach 2004-2008 na wieś i rolnictwo zostało wydane 66,6 mld zł, w tym 44,4 mld zł (tj. 67\%) pochodziło z UE.

Celem pracy jest przybliżenie zagadnień, uwzględniających rozwój rolnictwa w Polsce w ciągu 5 lat po przystąpieniu do UE oraz ukazanie możliwości jego rozwoju.

\section{Dochody rolników po przystąpieniu Polski do UE}

Dochody rolników po przystąpieniu Polski do UE, dzięki dopłatom bezpośrednim, wzrosły niemal 2-krotnie, jednak sytuacja materialna mieszkańców wsi jest nadal bardzo zróżnicowana (Tabela 1). Po objęciu polskiego rolnictwa Wspólną Polityką Rolną dochody rolników wzrosły, głównie dzięki unijnym dopłatom bezpośrednim. W 2003 roku średni dochód w przeliczeniu na 1 osobę o pełnym zatrudnieniu (tj. pracującą, co najmniej 2200 godzin rocznie w gospodarstwie rolnym) wynosił zaledwie $24 \%$ średniego wynagrodzenia netto w gospodarce narodowej, w 2004 roku wzrósł on do 56\%, a w kolejnych latach ulegał istotnym zmianom. Warto nadmienić, że dochody rolników są obliczane na podstawie szacunków, gdyż nie mają oni obowiązku prowadzenia pełnej ewidencji księgowej (Raport „Sytuacja ..., 2008). Podstawą wyliczeń są informacje uzyskane od 12 tys. gospodarstw towarowych, czyli takich które sprzedają produkcję na rynek.

Jeżeli przyjmiemy za 100\% dochody rolników w 2000 roku, to w 2003 roku wyniosły one $96 \%$, w 2004 roku wzrosły do $180,8 \%$, a w 2008 roku ukształtowały się na poziomie 182,5\%. W bardzo dobrym dla branży rolno-spożywczej 2007 roku dochody rolników stanowiły $221,6 \%$ w stosunku do 2000 roku. 
Próba oceny rozwoju polskiej wsi pięć lat po przystąpieniu do Unii Europejskiej

Tabela 1. Wybrane dane o dochodach i doplatach $w$ sektorze gospodarstw rolnych $w$ Polsce w latach 2003-2008 i ich dynamika

\begin{tabular}{|l|c|c|c|c|c|c|c|}
\hline \multirow{2}{*}{ Wyszczególnienie } & \multicolumn{5}{|c|}{ Lata } & \multirow{2}{*}{$\begin{array}{c}\text { Dynamika } \\
\mathbf{2 0 0 8 / 2 0 0 3}\end{array}$} \\
\cline { 2 - 8 } & 2003 & 2004 & 2005 & 2006 & 2007 & 2008 & 132 \\
\hline $\begin{array}{l}\text { Średnie wynagrodzenie netto } \\
\text { w gospodarce narodowej (zł) }\end{array}$ & 17622 & 18325 & 19060 & 19840 & 21570 & 23330 & 236 \\
\hline $\begin{array}{l}\text { Dochód na osobę } \\
\text { pełno - zatrudnioną (zł) }\end{array}$ & 4259 & 10290 & 8252 & 9984 & 12411 & 10062 & 178 \\
\hline $\begin{array}{l}\text { Wskaźnik dochodu do średniego } \\
\text { wynagrodzenia (\%) }\end{array}$ & 24,2 & 56,2 & 43,3 & 50,3 & 57,5 & 43,1 & 1249 \\
\hline $\begin{array}{l}\text { Dopłaty na osobę } \\
\text { pełno-zatrudnioną (zł) }\end{array}$ & 402 & 4009 & 3882 & 5198 & 5352 & 5019 & 531 \\
\hline Udział dopłat w dochodzie (\%) & 9,4 & 39,0 & 47,0 & 52,1 & 43,1 & 49,9 & \\
\hline
\end{tabular}

Źródło: Obliczenia własne na podstawie danych EAA i GUS.

Od 2004 roku nastąpiła też zmiana kierunku przepływu środków. Rolnictwo zaczęło otrzymywać więcej pieniędzy niż przekazywało do budżetu w formie podatków. W 2004 roku udział dopłat w dochodach rolniczych stanowił 39\%. W następnych latach był on jeszcze większy, ponieważ co roku dopłaty dla rolników wzrastały. W 2008 roku dopłaty bezpośrednie wynosiły 49,9\% dochodu rolniczego. Dla gospodarstw małych, o rocznym dochodzie poniżej 2400 euro rocznie (określonym według unijnej skali siły ekonomicznej gospodarstw, jako 2 esu), dopłaty dla rolników stanowią często główne źródło dochodów. Gospodarstwa, których w Polsce jest około 75\%, uważane są za tzw. gospodarstwa socjalne, tj. produkujące wyłącznie na własne potrzeby.

Istotne znaczenie mają dopłaty także dla gospodarstw największych, których dochody przekraczają 100 esu. Dopłaty do tych gospodarstw stanowią średnio powyżej 20\% dochodów. W Polsce gospodarstw tych jest zaledwie $0,11 \%$, ale powierzchnia ich wzrasta (Tabela 2).

Tabela 2. Dynamika zmian struktury gospodarstw w latach 1996-2007

\begin{tabular}{|l|c|c|c|c|c|}
\hline \multirow{2}{*}{ Powierzchnia gospodarstw } & \multicolumn{5}{|c|}{ Lata Dynamika } \\
\cline { 2 - 6 } & 1996 & 2002 & 2007 & $2002 / 1996$ & $2007 / 1996$ \\
\hline Gospodarstwa rolne ogółem w tys. & 3066,5 & 2933,2 & 2579,2 & 95,7 & 84,1 \\
- w tym bez działalności rolniczej & 303,1 & 755,6 & 188,2 & 249,3 & 62,1 \\
- do 1 ha & 1019,7 & 977,1 & 771,1 & 95,8 & 75,6 \\
- od 1do 5 ha & 1130,0 & 1146,9 & 1036,9 & 101,5 & 91,8 \\
- od 5 do 20 ha & 828,0 & 693,5 & 644,3 & 83,8 & 77,8 \\
- 20 ha i więcej & 88,4 & 115,8 & 126,8 & 131,0 & 143,4 \\
\hline
\end{tabular}

Źródło: Opracowanie własne na podstawie danych GUS. 
Rocznie o dopłaty bezpośrednie ubiega się w Polsce około 1,4 mln gospodarstw. W 2008 roku wnioski o dopłaty złożyło 1,45 mln rolników, a średnia powierzchnia gospodarstwa wynosiła około 10 hektarów. Do 2013 roku, zgodnie z Traktatem Akcesyjnym, polscy rolnicy będą otrzymywać dopłaty bezpośrednie w niepełnym wymiarze. W 2008 roku polscy rolnicy dostali 80\% poziomu płatności, uzyskiwanych w krajach starej UE. Podstawowa płatność rolnikom za 2008 rok wyniosła około $340 \mathrm{zł} \mathrm{za} 1$ hektar. W 2004 roku polskim rolnikom przysługiwało jedynie 55\% płatności (Sprawozdanie ..., 2008).

Według danych Agencji Restrukturyzacji i Modernizacji Rolnictwa (ARiMR) w latach 2004-2008 w postaci dopłat bezpośrednich do rolników trafiło prawie 38 mld zł, a w 2008 roku było to 10,3 mld zł. Prognoza Komisji Europejskiej, dotycząca dochodów rolników w latach 2005-2014 wskazuje, że realne dochody $\mathrm{w}$ przeliczeniu na osobę pełno zatrudnioną $\mathrm{w}$ rolnictwie $\mathrm{w}$ nowych krajach UE wzrosną o $32 \%$, pod warunkiem zmniejszenia w tym czasie zatrudnienia o około $22 \%$. Oznacza to zmniejszenie zatrudnienia w Polsce o około. 470 tys. osób, czyli z 2 mln 62 tys. obecnie do 1 mln 169 tys. osób.

Z analiz Instytutu Ekonomiki Rolnictwa i Gospodarki Żywnościowej (IERiGŻ) wynika, że dopłaty bezpośrednie stanowią poważne źródło dochodów rolniczych. Dzięki tym dopłatom dochód rolniczy podwoił się, ale stale jest niższy niż dochody osób zatrudnionych w innych działach gospodarki narodowej.

W ciągu 5 lat naszego członkostwa w UE eksport produktów rolno-spożywczych zwiększył się z 4,0 do 11,3 mld euro, a import z 3,6 do 9,8 mld euro. Szybciej rozwijała się również wymiana handlowa z innymi krajami UE. Dostawy żywności z Polski do krajów UE-25 w latach 2003-2005 zwiększyły się o 2,5-krotnie, a przywóz do naszego kraju wzrósł o nieco powyżej 2-krotnie. Poprawiło się dodatnie saldo handlu zagranicznego produktami rolno-spożywczymi: ogółem z 0,4 mld euro w 2003 roku do 1,5 mld euro w 2008 roku, z krajami UE-25 z 0,4 mld euro do 2,3 mld euro w 2008 roku, z krajami UE- 15 z 0,2 mld euro do 0,8 mld EURO w 2008 roku (w tym przypadku spadło, gdyż wynosiło po 1,5 mld w latach 20062007) i z krajami UE-12 z 0,2 mld euro do 1,5 mld euro w 2008 roku.

Wzrost cen w otoczeniu rynkowym był i jest niekorzystny zarówno dla rolników, jak i przetwórców. Wskaźniki wzrostu cen produktów rolnych i cen żywności były i są niższe od wskaźników inflacji i od dynamiki cen środków produkcji dla rolnictwa. Po wejściu Polski do UE globalna produkcja rolnictwa w cenach stałych wyniosła około 58,5 mld zł i była średnio o $2,5 \%$ wyższa niż w latach 2001-2003. W tym okresie produkcja zwierzęca wzrosła o 6,9\%, a produkcja roślinna obniżyła się o 1,1\% (Wieś ..., 2003). Po wejściu Polski do UE nastąpił przede wszystkim duży wzrost dostaw rynkowych mięsa oraz przetworów mięsnych. Jest to wynik uprzemysłowienia przetwórstwa rolno-spożywczego i jego koncentracji, wymuszonej przez procesy dostosowawcze do standardów unijnych. Działami rolnictwa, które po wejściu do UE wykazują wzrost produkcji, są 
sektor drobiarski oraz uprawa rzepaku, przede wszystkim ze względu na rosnący popyt na biopaliwa. Wzrostowy trend wykazywały także dostawy serów dojrzewających, napojów i deserów mlecznych, wyrobów czekoladowych i piwa oraz napojów bezalkoholowych.

Wejście Polski do UE nie wywarło istotnych zmian w poziomie produkcji tak ważnych działów polskiego rolnictwa, jak: zboża, mleko i mięso wieprzowe. Po wejściu do UE obniżyła się nieco produkcja owoców. Obecny jej poziom jest o około 15\% wyższy niż w latach 1998-2000 (Wilkin, 2001; Górz, 2003). Spadek spożycia żywności nastąpił tylko w pierwszym roku naszej akcesji do UE i wynikał on głównie z dużego wzrostu cen żywności i napojów bezalkoholowych. Spadek spożycia żywności zahamowany został w 2005 roku, a od 2006 roku na większości rynków odnotowano ponowny wzrost popytu na produkty rolno-spożywcze (Ryś-Jurek, 2008).

Po wejściu Polski do UE nastąpiło ożywienie produkcyjne w przemyśle spożywczym. Wartość produkcji sprzedanej przemysłu spożywczego od 2003 roku zwiększała się w tempie od 6 do 7\% rocznie. To ożywienie trwa nadal, gdyż pod wpływem wzrostu dochodów rozwija się krajowy rynek żywności i napojów oraz rośnie orientacja eksportowa przedsiębiorstw przemysłu spożywczego, co wyraża się we wzroście udziału eksportu w sprzedaży (Ryś-Jurek, 2008).

Lata bezpośrednio poprzedzające członkostwo oraz pierwsze 5 lat członkostwa są okresem, w którym rolnictwo i regiony wiejskie otrzymywały wsparcie finansowe $\mathrm{z}$ budżetu UE. W latach 2004-2008 środki na rozwój rolnictwa i regionów wiejskich pochodziły z programów wieloletnich i Programu Przedakcesyjnego SAPARD (Tabela 3).

Tabela 3. Środki publiczne współfinansujące programy rozwoju wsi w latach 2004-2008 wypłacone beneficjentom (środki publiczne krajowe i unijne)

\begin{tabular}{|l|c|}
\hline \multicolumn{1}{|c|}{ Nazwa programu } & $\begin{array}{c}\text { Wypłacone środki w mld zl } \\
\text { (dane szacunkowe) }\end{array}$ \\
\hline Program SAPARD & 2 \\
\hline Program Rozwoju Obszarów Wiejskich (PROW) 2004-2006 & 6 \\
\hline $\begin{array}{l}\text { Restrukturyzacja i Modernizacja Sektora Żywnościowego } \\
\text { (SPO) oraz Rozwój Obszarów Wiejskich (PROW) 2004-2006 }\end{array}$ & 4 \\
\hline Program Rozwoju Obszarów Wiejskich 2007-2013 & 26 \\
\hline Ogółem & 6 \\
\hline
\end{tabular}

Źródło: Opracowanie własne na podstawie danych GUS.

Wyniki handlu zagranicznego świadczą o dużej konkurencyjności polskich producentów żywności na rynkach zagranicznych i wskazują, że nasza oferta eksportowa jest zarówno bezpieczna i dobra jakościowo, jak i atrakcyjna cenowo dla zagranicznych konsumentów. Konkurencyjność polskich producentów żyw- 
ności wynika przede wszystkim z posiadania przez nich przewagi o charakterze kosztowo-cenowym. Polska ma wyraźną przewagę cenową (niższe ceny) na wielu rynkach podstawowych produktów rolnych. Wśród grup produktów o relatywnie najwyższej pozycji konkurencyjnej na Jednolitym Rynku Europejskim (JRE) dominują produkty pracochłonne (Raport „Polska Wieś 2008”).

Mimo obserwowanych pozytywnych przeobrażeń, skuteczne konkurowanie z pozostałymi państwami Wspólnoty utrudnia nadal stosunkowo niski poziom koncentracji produkcji rolniczej i przetwórstwa żywności, niska wydajność pracy w przemyśle spożywczym oraz mało aktywny marketing i promocja polskich produktów rolno-spożywczych. Należy zwrócić uwagę, że potencjał produkcyjny i eksportowy oraz pozycja konkurencyjna polskiego sektora rolno-spożywczego po przystąpieniu do UE kształtuje się w ramach ograniczeń, wyznaczonych przez niepełny poziom płatności bezpośrednich.

Po akcesji Polski do UE okazało się, że zagrożenia są mniejsze niż wcześniej oceniano, a nasi producenci żywności dobrze wykorzystują szanse, jakie powstały w wyniku otwarcia dużego i zamożnego europejskiego rynku żywności. Polska gospodarka żywnościowa jest dobrze przygotowana do prowadzenia działalności na Wspólnym Rynku Europejskim.

\section{Podsumowanie}

W ciągu 5 lat poprawiły się dochody zarówno małych, jak i dużych gospodarstw. Największy skok dochodów był w pierwszym roku akcesji, gdy koszty produkcji nie były jeszcze tak wysokie. W następnych latach wzrosły ceny środków produkcji oraz koszty pracy. Polska otrzymała z UE duże środki na rolnictwo, a polityka rolna nie zależała od polskiego rządu. Wymuszenie przez Unię dostosowania polskiego rolnictwa i przemysłu przetwórczego do unijnych norm było w rezultacie korzystne dla rozwoju agrobiznesu. Poprawienie standardów i tak było konieczne, gdyż bez unijnych certyfikatów nie można było eksportować żywności do krajów Wspólnoty.

Konieczność podnoszenia standardów produkcji była bardzo dużym obciążeniem dla rolników i przemysłu przetwórczego. Niektóre wymagania polskich służb weterynaryjnych były wielokrotnie zbyt wygórowane. Wynikało to $\mathrm{z}$ nadinterpretacji przepisów unijnych przez różne inspekcje, kontrolujące jakość żywności. Wysokie standardy wymuszano na małych firmach, np. masarniach czy mleczarniach, co doprowadziło do masowego zamykania takich zakładów.

Negatywnie należy ocenić negocjacje akcesyjne. Uzgodniono zbyt małe limity produkcyjne. Ponadto Polska weszła do UE na gorszych zasadach. Dotyczy to m.in. niższych dopłat bezpośrednich w porównaniu z krajami, będącymi już w Unii. W 2004 roku polscy rolnicy otrzymywali jedynie 55\% dopłat, przyznawanych rolnikom $\mathrm{z}$ krajów starej UE. 
Niekorzystna była również dla nas unijna reforma rynku cukru, która zmusiła przemysł cukrowniczy do zmniejszenia produkcji. Z eksportera cukru Polska stała się importerem. Ludzie utracili miejsca pracy, a plantatorzy musieli zrezygnować z produkcji buraków cukrowych.

Wzajemne pełne otwarcie rynków nie było hamulcem rozwoju polskiej gospodarki żywnościowej, lecz stało się dla niej silnym impulsem rozwoju. W ciągu 5 lat naszego członkostwa w UE eksport produktów rolno-spożywczych zwiększył się z 4,0 do 11,3 mld euro, a import z 3,6 do 9,8 mld euro, natomiast nadwyżka wzrosła 3,3-krotnie z 0,4 do 1,5 mld euro. Jeszcze szybciej rozwijała się wymiana handlowa $\mathrm{z}$ innymi krajami UE.

Członkostwo w UE nadało nowy, bardzo silny impuls eksportowi polskich produktów rolno-spożywczych do krajów UE. Wzrost dynamiki handlu z tymi krajami i poprawa wyników nastąpiły szczególnie w ostatnich latach, podczas kiedy w handlu z UE-15 obserwowano spadek dynamiki i pogorszenie wyników.

Reasumując można stwierdzić, że kondycja polskiego rolnictwa jest obecnie na poziomie dostatecznym. Ocenę taką potwierdzają przytoczone dane: EAA, GUS i MRiRW, co stanowiło cel niniejszej pracy. Pieniądze otrzymywane z UE raczej nie wystarczą na zmodernizowanie polskiego rolnictwa i potrzebna będzie polityka narodowa dla wsi. Wspólna polityka rolna UE powinna być podtrzymana także po 2013 roku. Polski nie stać na finansowanie rolnictwa w takim stopniu, jak to jest możliwe w najbogatszych krajach UE.

\section{Bibliografia}

BAŃski J., Przestrzenny wymiar współczesnych procesów na wsi (t. 9), wyd. Studia Obszarów Wiejskich, Warszawa, 2006, s. 46.

Chmielewska M., Polskie gospodarstwa rolne w aspekcie integracji z Unią Europejską, korzyści i zagrożenia, Rocz. Nauk. SERiA, SGGW, t. VIII, z. 1, 2006, s. 17.

Górz B., Guzık Cz., Współczesne przekształcenia i przyszłość polskiej wsi (t. 4), Wyd. Studia Obszarów Wiejskich, Warszawa, 2003, s. 78.

Raport „Polska Wieś 2008”, Wyd. Fundacja na Rzecz Rozwoju Polskiego Rolnictwa, Warszawa, s. 34.

Raport „Sytuacja ludzi młodych na rynku pracy na obszarach wiejskich w Polsce”, Wyd. Fundacja na Rzecz Rozwoju Polskiego Rolnictwa, Warszawa, 2008, s. 28.

RYś-Jurek R., Dochodowość polskich indywidualnych gospodarstw rolnych jako element ich konkurencyjności w Unii Europejskiej w 2005 roku, Rocz. Nauk. SERiA, SGGW, t. X, z. 3, 2008, s. 45.

RYś-JUREK R., Ocena sytuacji ekonomicznej indywidualnych gospodarstw rolnych z wykorzystaniem wybranych metod ilościowych, Wyd. AR im. A. Cieszkowskiego, Poznań, 2008, s. 128.

Sprawozdanie z regionalnej debaty „Pytania o przyszłość polskiej wsi” z dnia 19 grudnia 2008, Kielce, s. 19.

Wieś polska w nowej Europie, Wyd. Fundacja na Rzecz Rozwoju Polskiego Rolnictwa, Warszawa, 2003, s. 97.

Wilkin J., Kolarska-Bobińska L., Rosner A., Przyszłość wsi polskiej: wizje, strategie, koncepcje, Wyd. Instytut Spraw Publicznych, Warszawa, 2001, s. 61. 


\title{
Assessment trial of the Polish countryside development five years after the accession to the European Union
}

\begin{abstract}
SUMMARY
The objective of this article is familiarisation with the issues relating to agricultural development in Poland and its perspectives for the future. A trial to assess the development of the Polish agricultural areas has been made five years after the accession to the European Union. The analysis has been performed on the basis of the data from Economical Accounts for Agriculture (EAA), the Central Statistical Office (GUS) and the Ministry of Agriculture and Rural Development (MRiRW). Chosen data on income and subsidies in the farm sector in Poland between 2003 and 2008 have been quoted. The analysis of the statistical data shows that farmers' income after the Poland's accession to the EU has risen nearly twice but the financial situation of people living in the agricultural areas is still very diversified. Their income has increased thanks to the EU direct subsidies. The integration between Poland and the European Union has created additional opportunities for growth in the food and agriculture sector. For five years of the Polish membership in the EU the export of farm and food products has nearly tripled.
\end{abstract}

Keywords: agricultural areas, development, agriculture, income

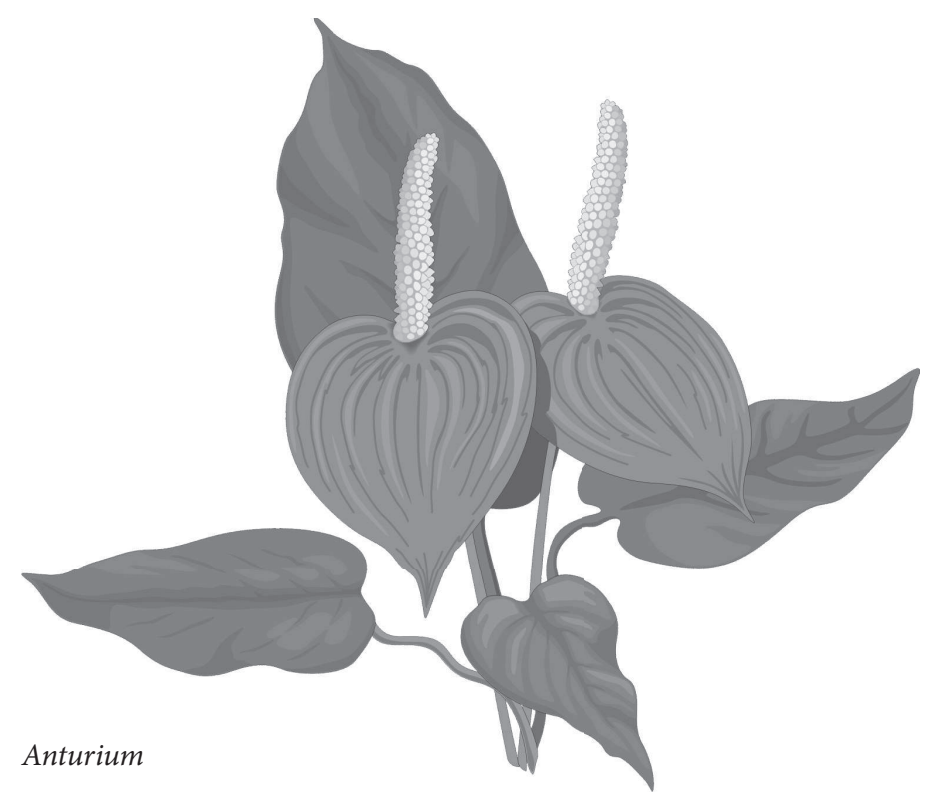

